Jurnal Informatika dan Rekayasa Perangkat Lunak (JATIKA)
Vol. 1, No. 2, December 2020, 245-253
ISSN 2723-3367
available online at:http:///im.teknokrat.ac.id/index.php/informatika

\title{
SISTEM INFORMASI PENERIMAAN SISWA BARU BERBASIS WEB (STUDI KASUS SMA FATAHILLAH SIDOHARJO JATI AGUNG LAMPUNG SELATAN)
}

\author{
Andri Agus Irawan', Neneng ${ }^{2}$ \\ S1 Informatika, Universitas Teknokrat Indonesia \\ Andriagusirawan@gmail.com
}

Received: (date month year)Accepted: (date month year) Published: (date month year )

\begin{abstract}
Information technology is very developed in society, generally information technology is a technology that is used to manage data, process, store and manipulate data in various ways and procedures to produce high quality and useful information, especially at SMA Fatahillah Sidoharjo Jati Agung. From this identification, SMA Fatahillah Lampung Selatan needs a web-based student admission information system that is able to process new student data so that data can be stored safely into a database system. This research was carried out by designing a Usecase Diagram, Activity Diagram and Flowchart. The result of this research is a web-based admission information system (Case study: SMA Fatahillah Sidoharjo Jati Agung Lampung Selatan), which can provide admission information or new student registration and can be accessed online without limited space and time. Based on testing using a blackbox, that the application for new student admissions at Fatahillah High School went as expected.
\end{abstract}

Keywords: Information System, Registration, Testing, Usecase, Web.

\begin{abstract}
Abstrak
Teknologi informasi sangat berkembang di masyarakat, umumnya teknologi informasi adalah sebuah teknologi yang dipergunakan untuk mengelola data, memproses, menyimpan dan memanipulasi data dengan berbagai macam cara dan prosedur guna menghasilkan informasi yang berkualitas dan bernilai guna tinggi, khususnya di SMA Fatahillah Sidoharjo Jati Agung. Dari identifikasi tersebut, SMA Fatahillah Lampung Selatan membutuhkan suatu sistem informasi penerimaan siswa berbasis web yang mampu mengolah data-data siswa baru sehingga data dapat disimpan dengan aman kedalam database system. Pada penelitian ini dilakukan dengan perancangan Usecase Diagram, Activity Diagram dan Flowchart. Hasil dari penelitian ini yaitu sebuah sistem informasi penerimaan siswa baru berbasis web (Studi kasus : SMA Fatahillah Sidoharjo Jati Agung Lampung Selatan), yang dapat memberikan informasi penerimaan atau pendaftaran siswa baru dan dapat diakses secara online tanpa terbatas ruang dan waktu. Berdasarkan pengujian menggunakan blackbox, bahwa aplikasi penerimaan siswa baru di SMA Fatahillah berjalan sesuai dengan yang diharapkan.
\end{abstract}

Kata Kunci: Pendaftaran, Pengujian, Sistem Informasi, Usecase, Web.

\section{To cite this article:}

Andri Agus Irawan, Neneng. (2020). SISTEM INFORMASI PENERIMAAN SISWA BARU BERBASIS WEB (STUDI KASUS SMA FATAHILLAH SIDOHARJO JATI AGUNG LAMPUNG SELATAN). Jurnal Informatika dan Rekayasa Perangkat Lunak, Vol(1) No(2), 245-253.

\section{PENDAHULUAN}

Penggunaan teknologi informasi saat ini sangat beragam, salah satunya adalah penggunaan teknologi informasi dan komunikasi, seperti teknologi internet dan web yang dapat memberikan informasi secara cepat dan tepat (Mulyanto, Nurhuda and Khoirurosid, 2017). Teknologi informasi sangat berkembang di masyarakat, secara 
umum teknologi informasi adalah teknologi yang digunakan untuk mengelola data, mengolah, menyimpan dan memanipulasi data dengan berbagai cara dan prosedur untuk menghasilkan informasi yang berkualitas dan berguna (Setiawansyah, Sulistiani and Darwis, 2020). Seiring bertambahnya kebutuhan manusia, perkembangan teknologi informasi pun terus berkembang.

Sistem pendaftaran mahasiswa baru SMA Fatahillah saat ini belum menggunakan sistem komputerisasi. Butuh waktu dan biaya untuk mendaftar atau mendaftar menggunakan sistem ini untuk mencapai SMA Fatahillah untuk pendaftaran. Proses pendaftaran yang sedang berjalan berarti siswa harus berangkat ke sekolah untuk mengumpulkan dan mengisi formulir pendaftaran yang disediakan panitia. Sistem untuk pendaftaran belum terkomputerisasi, karena calon siswa harus mengisi formulir pendaftaran secara tertulis yang biasanya mengakibatkan hilang formulir atau formulir dan beberapa Kerusakan kandidat. Mahasiswa seringkali lupa membuat persyaratan pendaftaran, sehingga calon mahasiswa harus kembali ke kampung halamannya untuk melengkapi persyaratan tersebut. Penyimpanan data untuk pendaftaran mahasiswa baru belum terkomputerisasi, sehingga banyak file dan data yang sering dimasukkan kembali, dan proses pencarian data menjadi sulit.

Sistem informasi berbasis web berbasis teknologi internet harus dikembangkan agar calon mahasiswa lebih mudah mendaftar dan memperoleh informasi penerimaan mahasiswa baru, yang dapat diakses dari jauh kapanpun dan dimanapun melalui jaringan internet, dan dapat diakses dengan mudah dan cepat, sehingga hemat Biaya dan waktu (Rahmanto, Hotijah and Damayanti, 2020).

Berdasarkan identifikasi permasalahan tersebut maka SMA Fatahillah Lampung Selatan membutuhkan sistem informasi penerimaan siswa berbasis web yang dapat mengolah data calon siswa baru sehingga data tersebut dapat tersimpan dengan aman dalam sistem database (Sintaro, Surahman and Prastowo, 2020). Dengan bantuan sistem informasi, mahasiswa diharapkan dapat melakukan proses pendaftaran sendiri, memanfaatkan internet untuk mengisi formulir pendaftaran dan mencetak kartu ujian, sehingga memudahkan pengoperasian kapanpun dan dimanapun, serta data tersimpan dengan benar dan aman (Megawaty et al., 2020).

Diharapkan proses pendaftaran mahasiswa baru dapat diselesaikan dengan cepat dan mudah sehingga proses seleksi dapat diselesaikan dengan cepat dan datanya tersimpan dengan aman di database. Oleh karena itu, perlu dikembangkan sistem informasi penerimaan siswa baru di SMA Fatahillah Lampung Selatan yang berbasis jaringan dan diharapkan dapat meminimalisir kesalahan dalam pendataan serta memudahkan calon siswa untuk melakukan pendaftaran.

\section{TELAAH PUSTAKA Sistem}

Sistem merupakan jaringan program yang dibuat menurut model terintegrasi untuk melaksanakan kegiatan utama perusahaan (Mulyadi, 2011). Sistem adalah rangkaian dari dua atau lebih komponen yang saling berhubungan yang berinteraksi untuk mencapai suatu tujuan. Kebanyakan sistem terdiri dari subsistem yang lebih kecil yang mendukung sistem yang lebih besar (Romney et al., 2012).

\section{CodeIgniter}

CodeIgneter merupakan framework pengembangan aplikasi dengan menggunakan PHP dan framework untuk pemrograman menggunakan PHP. Dengan mengikuti build framework yang disiapkan oleh framework CI ini, developer dapat segera membuat program dengan cepat (Destiningrum and Adrian, 2017; Wulandari and Sulistiani, 2020). Dengan menggunakan kerangka kerja, tidak perlu membuat program dari awal, tetapi kami telah menyediakan perpustakaan fungsi yang dapat diatur untuk membuat program dengan cepat. Kita hanya perlu memanggil fungsi yang ada untuk memproses data, lalu memanggil fungsi tersebut untuk menampilkannya. Anda dapat melihat alur kerja framework CodeIgniter di solusi alur framework CodeIgniter untuk memahami proses pengembangan Web dengan mudah (Sidik, 2018).

\section{METODE PENELITIAN} Kerangka Penelitian

Kerangka penelitian merupakan hubungan antar konsep-konsep yang akan dilakukan dalam penelitian (Ahmad $e t$ al., 2019). 


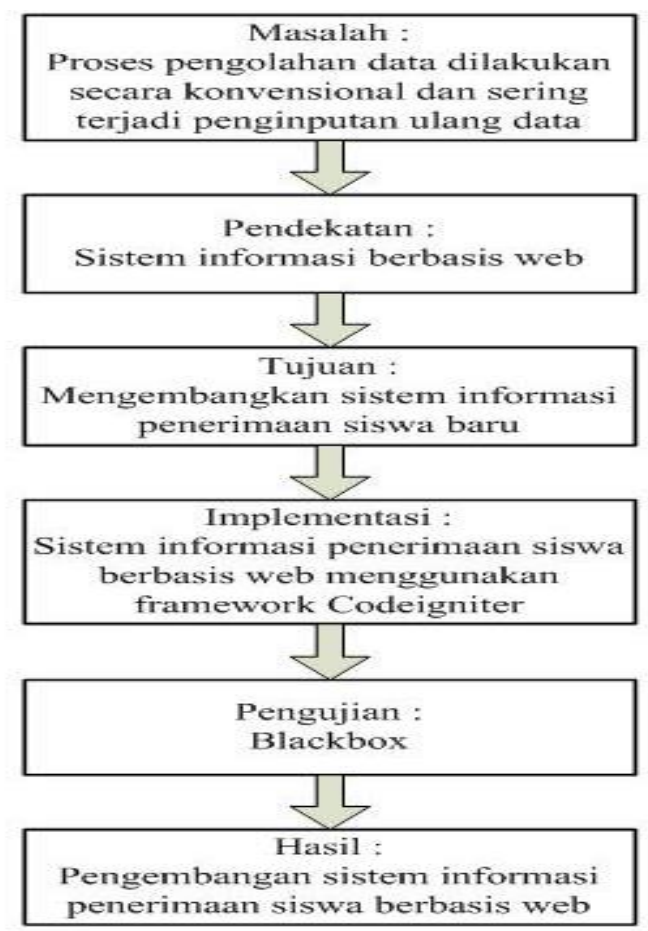

Gambar 1. Kerangka Penelitian

\section{Teknik Pengumpulan Data} adalah:

Proses pengumpulan data yang diperlukan dalam penelitian ini menggunakan beberapa metode pengumpulan data

1. Studi Literature

Metode pengumpulan data ini dilakukan dengan cara mengkaji literatur baik berupa jurnal, dokumen atau sumber bacaan, skripsi, dan buku mengenai topik usulan dalam penelitian.

2. Wawancara

Wawancara dilakukan langsung terhadap guru/staff yang ada di SMA Fatahillah untuk mendapatkan data dan informasi yang dibutuhkan dalam penelitian (Data wawancara terlampir).

3. Observasi

Observasi atau pengamatan dilakukan langsung pada SMA Fatahillah dengan melakukan pengamatan proses penerimaan siswa yang berjalan disana. Hasil observasi yang telah dilakukan, proses penerimaan siswa baru pada SMA Fatahillah dilakukan yaitu dengan cara calon siswa datang langsung ke sekolah untuk melakukan pendaftaran. Calon siswa mengisi formulir pendaftaran siswa baru, melengkapi syarat pendaftaran, dan membayar biaya pendaftaran sebesar Rp. 50.000.

\section{Analisis Sistem Berjalan}

Sistem pendaftaran dan penyimpanan data penerimaan siswa pada SMA Fatahillah masih dilakukan secara konvensional dan penyimpanan data disimpan secara manual dengan diarsipkan pada ordner. Sistem berjalan ini dapat dilihat pada bagan alir dokumen yang dapat dilihat pada gambar 


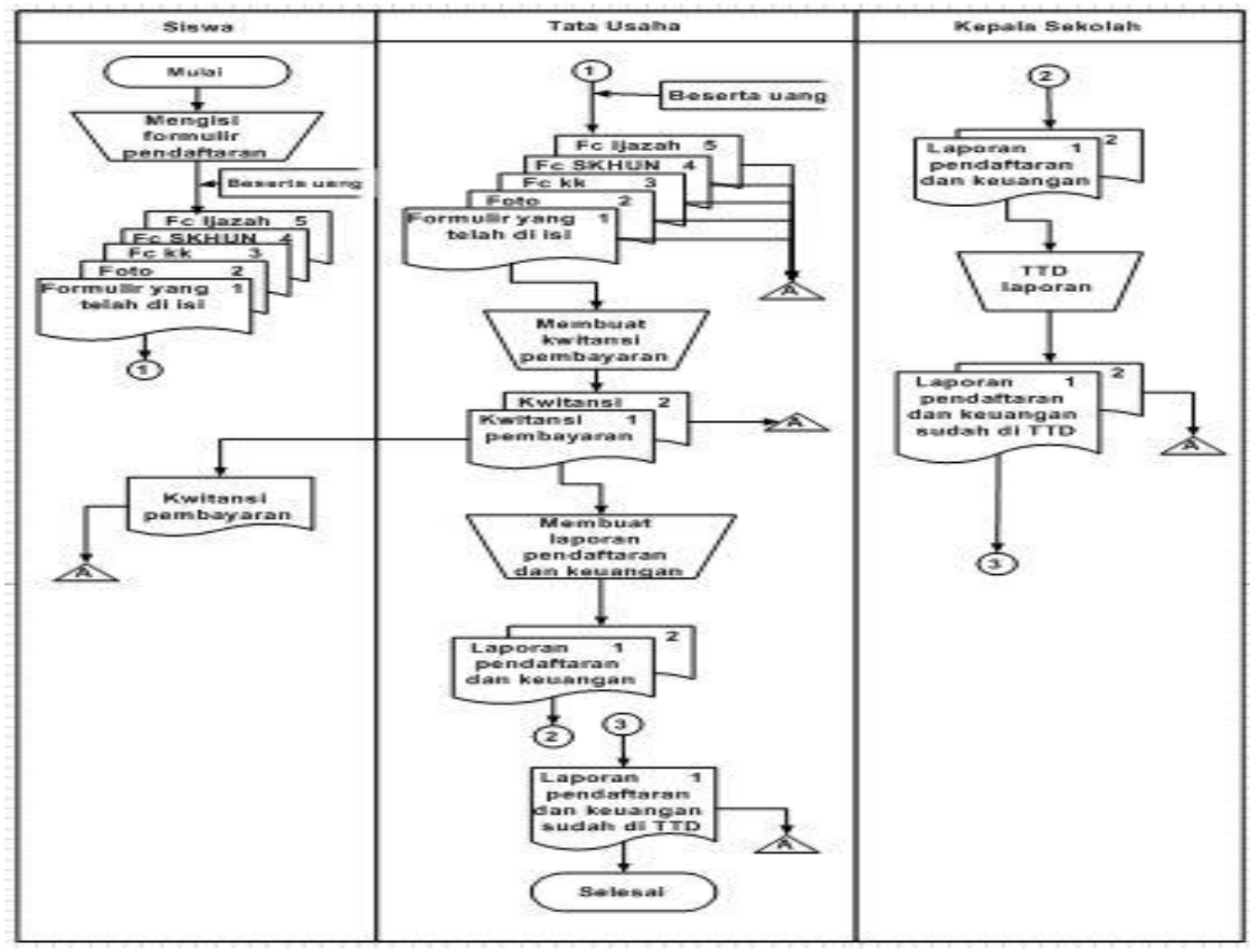

Gambar 2. Prosedur Sistem Berjalan

\section{HASIL DAN PEMBAHASAN}

\section{Perancangan Sistem}

Use case diagram adalah diagram yang digunakan untuk memodelkan perilaku sistem (Darwis et al., 2020). Use case menggambarkan interaksi antara pengguna sistem dan sistem. Use case diagram dapat dilihat pada gambar

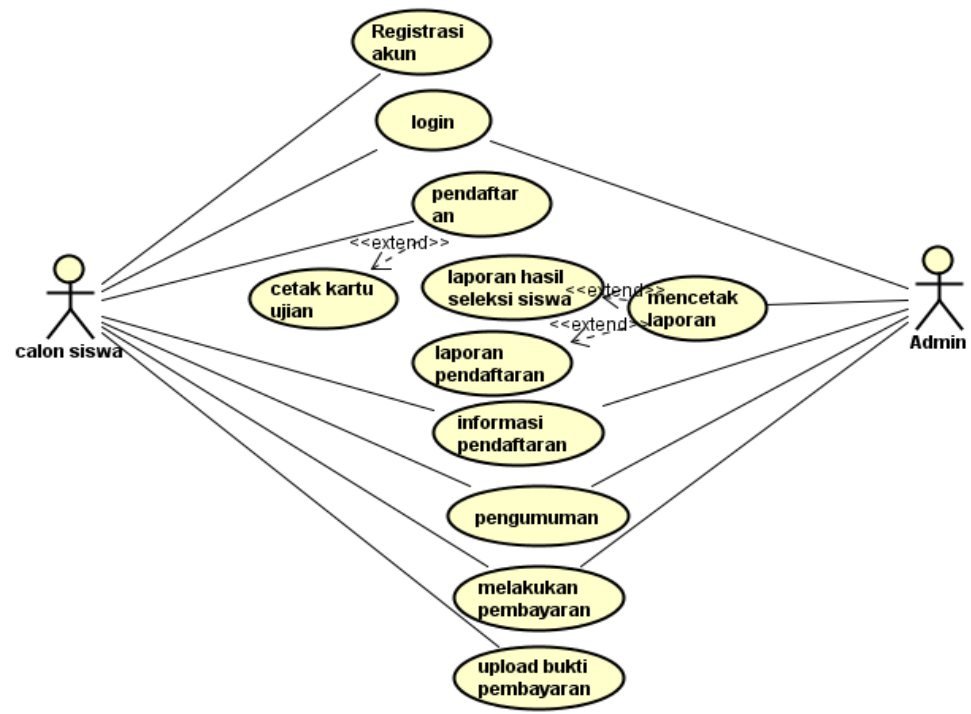

Gambar 3. Usecase Diagram 


\section{Implementasi Sistem}

Halaman utama web berisikan menu menu yang dapat digunakan untuk mengakses sistem penerimaan peserta didik baru pada SMA Fattahillah, di dalam menu Home, Daftar, Pendaftar, Informasi dan Login. Halaman utama web dapat dilihat pada gambar 4. sebagai berikut

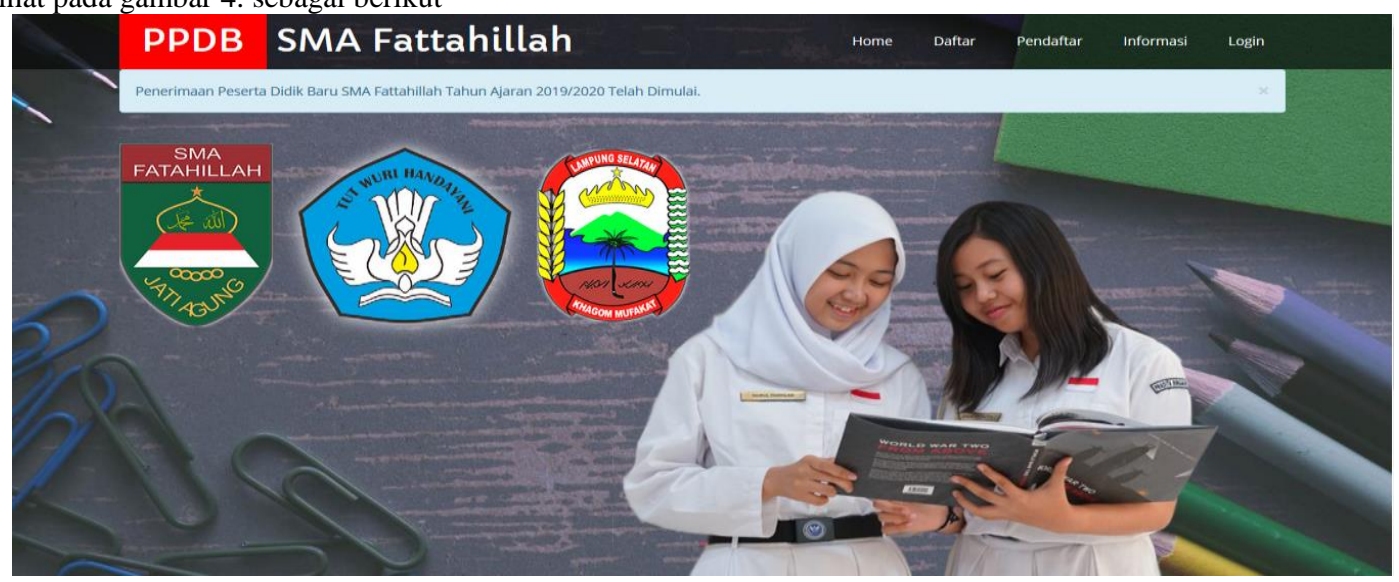

Gambar 4. Halaman Utama

Halaman Daftar berisikan form untuk calon siswa mendaftar sebagai user yang sah mengakses sistem penerimaan peserta didik baru SMA Fattahillah Jati Agung. Hasil implementasi halaman daftar dapat dilihat pada gambar 5 sebagai berikut

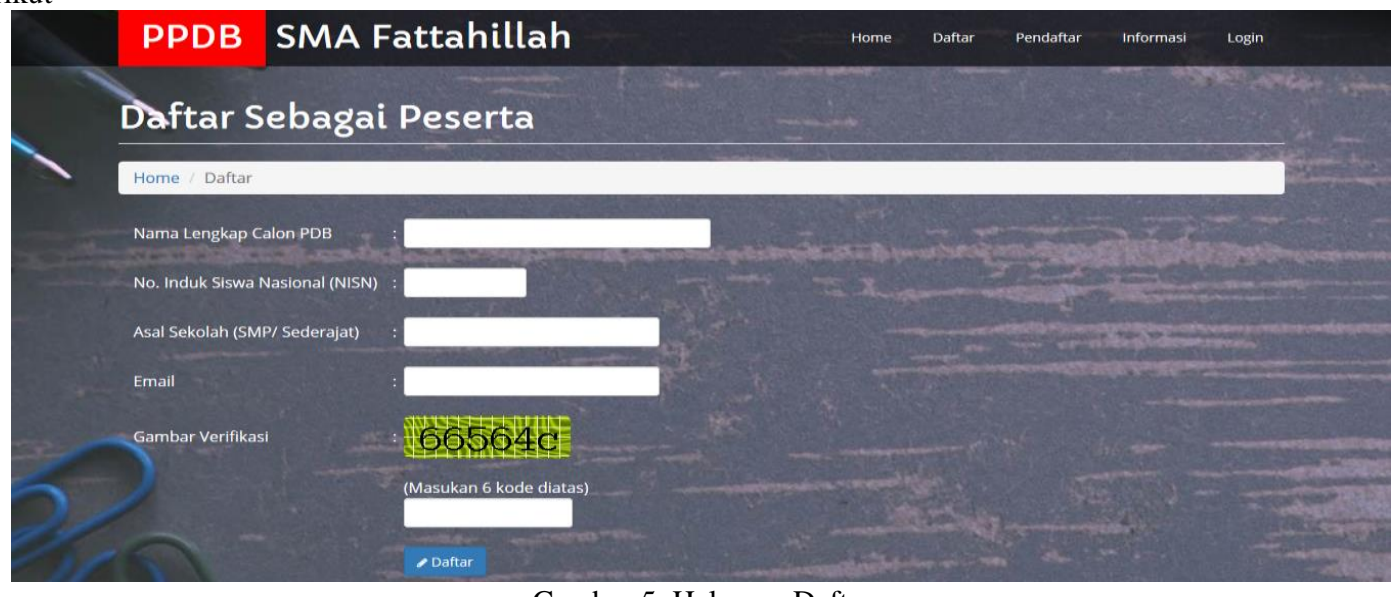

Gambar 5. Halaman Daftar

Halaman Info Akun Pendaftaran berisikan informasi tentang pendaftaran berhasil yang menampilkan akun yang harus calon siswa catat untuk login. Hasil implementasi halaman info akun pendaftaran dapat dilihat pada gambar 4 berikut

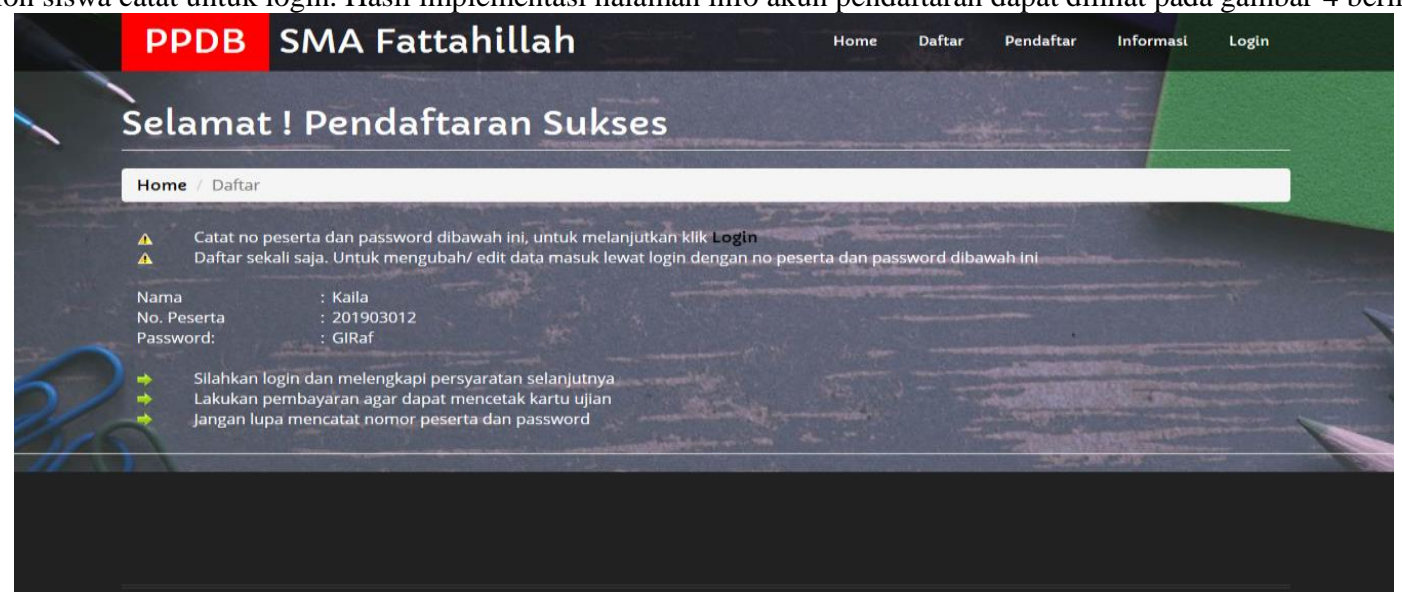


Gambar 6. Halaman Info

Halaman pendaftar merupakan halaman yang berisi daftar dari calon siswa SMA Fattahillah yang mendaftar dan terdapat informasi data yang sudah di verifikasi dan yang belum diverifkasi. Halaman pendaftar dapat dilihat sebagai berikut

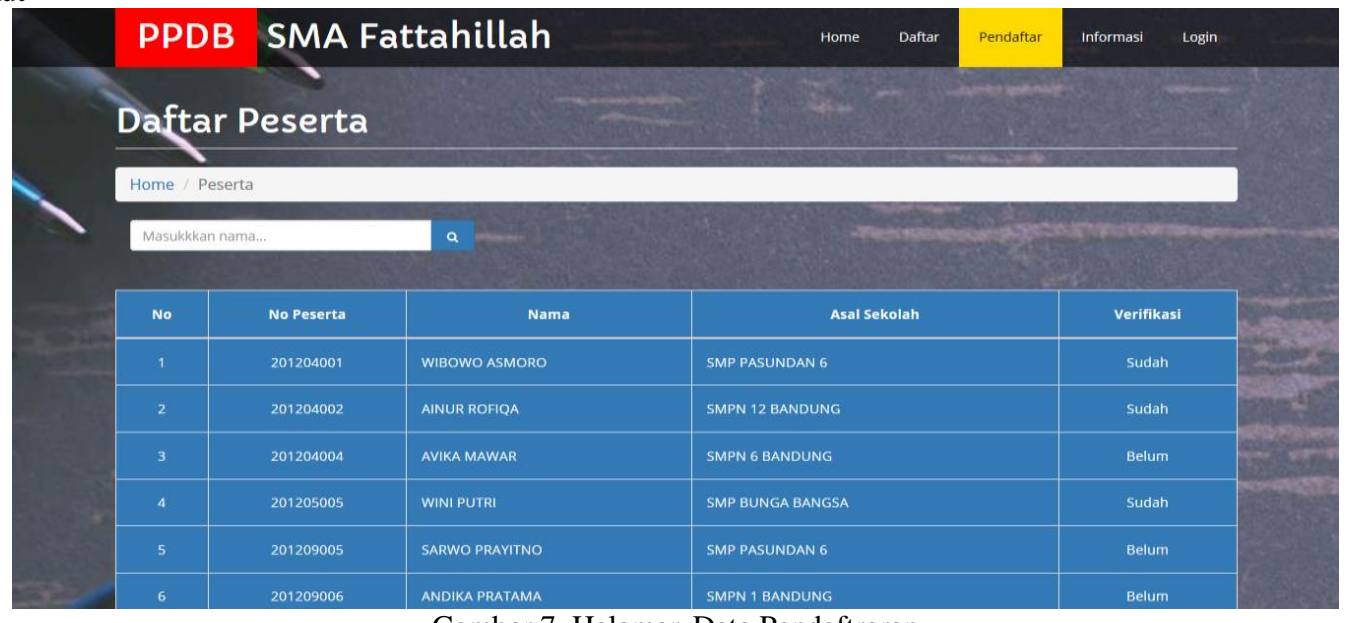

Gambar 7. Halaman Data Pendaftraran

Halaman Akun berisikan halaman tentang Biodata, Scan Dokumen, Bukti Pembayaran dan Cetak Dokumen. Hasil implementasi halaman akun dapat dilihat sebagai berikut

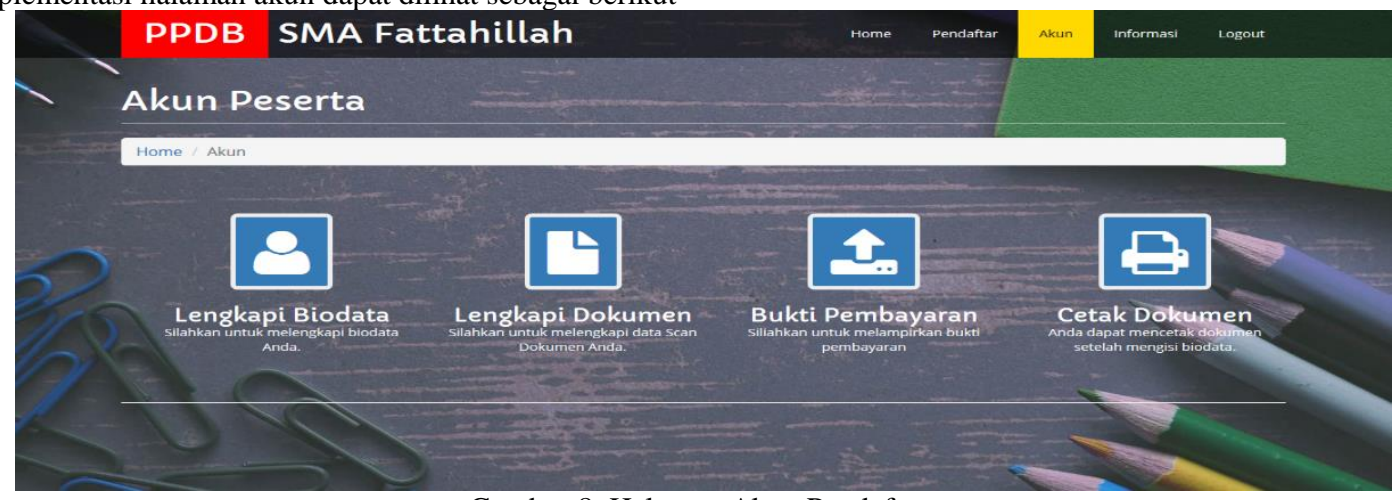

Gambar 8. Halaman Akun Pendaftrar

Halaman biodata merupakan halaman yang berisikan seluruh data calon siswa yang harus di isi sebagai salah satu proses verifikasi berkas berupa biodata calon siswa. Halaman biodata dapat dilihat pada gambar 9 sebagai berikut

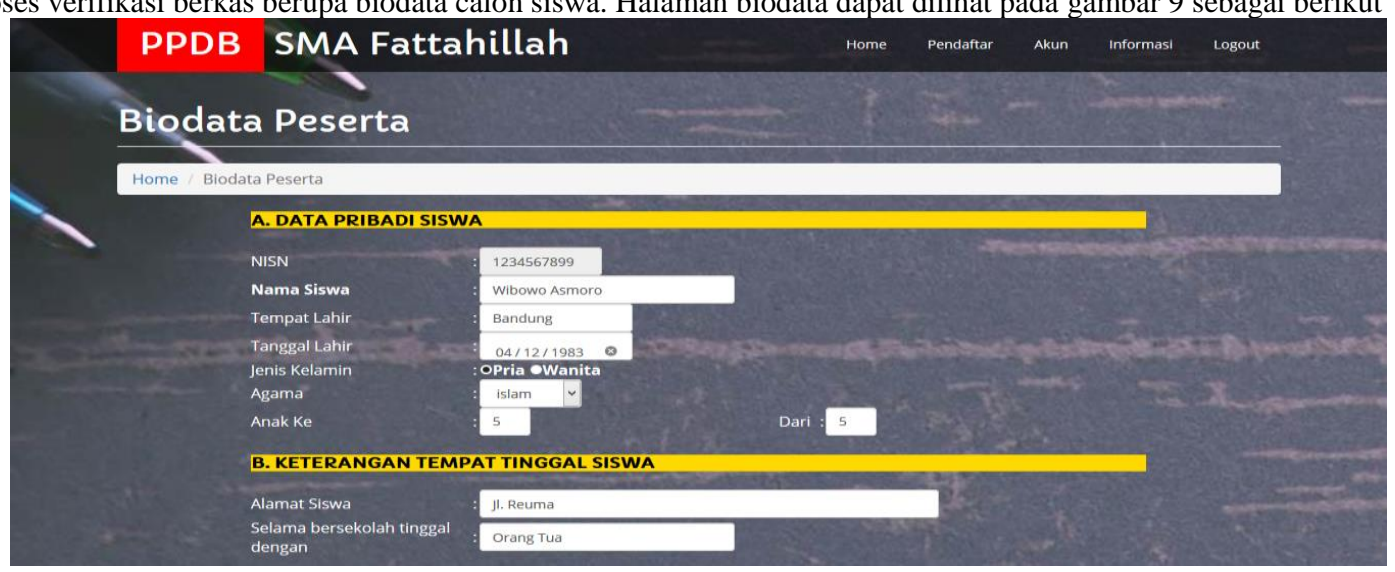

Gambar 10. Halaman Biodata 
Halaman pengumuman hanya dapat diakses pada saat setelah tahap tes seleksi dilakukan. Hasil implementasi halaman pengumuman dapat dilihat pada gambar 11 sebagai berikut

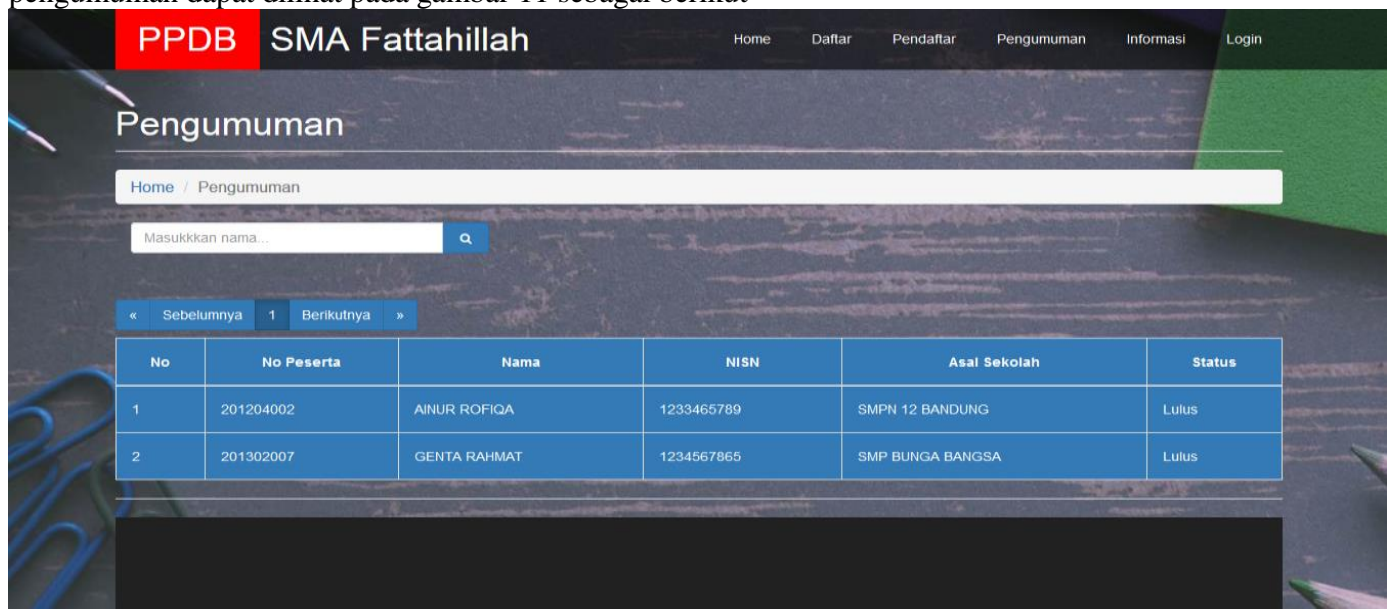

Gambar 11. Halaman Data Pengumuman

\section{Pengujian Sistem}

Pengujian yang dilakukan dalam sistem menggunakan metode black box. Pengujian ini menitik beratkan pada fungsi sistem. Tabel hasil pengujian dapat dilihat pada tabel 1 dibawah ini

Tabel 1. Hasil Pengujian

\begin{tabular}{|c|c|c|c|}
\hline $\begin{array}{l}\text { Masukan } \\
\text { Program }\end{array}$ & Yang diharapkan & Pengamatan & Hasil \\
\hline Membuka Web & Tampil form login & Dapat menampilkan Halaman Utama & Sesuai \\
\hline Validasi Login & $\begin{array}{ll}\text { Akan menampilkan } \\
\text { validasi Login } \\
\text { Akun yang Sah }\end{array}$ & $\begin{array}{l}\text { Jika Login benar maka akan muncul notifikasi "Sukses" } \\
\text { dan akan masuk ke Menu Utama, Jika Login salah maka } \\
\text { akan tampil notifikasi "Gagal , Username atau Password } \\
\text { Salah" }\end{array}$ & Sesuai \\
\hline $\begin{array}{l}\text { Memilih Menu } \\
\text { Home }\end{array}$ & $\begin{array}{l}\text { Menampilkan Halaman } \\
\text { Home }\end{array}$ & Dapat masuk ke Halaman Home & Sesuai \\
\hline $\begin{array}{l}\text { Memilih Menu } \\
\text { Daftar }\end{array}$ & $\begin{array}{l}\text { Menampilkan Halaman } \\
\text { Form Daftar }\end{array}$ & $\begin{array}{l}\text { Dapat daftar dan masuk kehalaman } \\
\text { Pendaftaran }\end{array}$ & Sesuai \\
\hline $\begin{array}{l}\text { Memilih Menu } \\
\text { Pendaftar }\end{array}$ & $\begin{array}{l}\text { Menampilkan halaman } \\
\text { pendaftar }\end{array}$ & Dapat menampilkan daftar pendaftar & Sesuai \\
\hline $\begin{array}{l}\text { Memilih Menu } \\
\text { Login }\end{array}$ & $\begin{array}{l}\text { Menampilkan halaman } \\
\text { login }\end{array}$ & Masuk kedalam sistem penerimaan siswa baru & Sesuai \\
\hline $\begin{array}{l}\text { Memilih Menu } \\
\text { Akun }\end{array}$ & $\begin{array}{l}\text { Menampilkan sub menu } \\
\text { Biodata, } \\
\text { Pembayaran dan Cetak } \\
\text { Dokumen }\end{array}$ & Masuk dalam sub menu masing masing & Sesuai \\
\hline $\begin{array}{l}\text { Memilih Menu } \\
\text { Informasi }\end{array}$ & $\begin{array}{l}\text { Menampilkan halaman } \\
\text { informasi }\end{array}$ & $\begin{array}{l}\text { Dapat menampilkan informasi mengenai penerimaan } \\
\text { siswa baru }\end{array}$ & Sesuai \\
\hline $\begin{array}{l}\text { Memilih Menu } \\
\text { Pengumuman }\end{array}$ & $\begin{array}{l}\text { Menampilkan halaman } \\
\text { pengumuman }\end{array}$ & Dapat menampilkan peserta yang lulus & Sesuai \\
\hline $\begin{array}{l}\text { Memilih Menu } \\
\text { Logout }\end{array}$ & $\begin{array}{l}\text { Menampilkan halaman } \\
\text { utama }\end{array}$ & Menuju halaman utama & Sesuai \\
\hline Membuka Web & Tampil form login & Dapat menampilkan Halaman Utama & Sesuai \\
\hline Validasi Login & $\begin{array}{l}\text { Akan menampilkan } \\
\text { validasi Login } \text { Untuk } \\
\text { Akun yang Sah }\end{array}$ & $\begin{array}{l}\text { Jika Login benar maka akan muncul notifikasi "Sukses" } \\
\text { dan akan masuk ke Menu Utama, Jika Login salah maka } \\
\text { akan tampil notifikasi "Gagal , Username atau Password } \\
\text { Salah" }\end{array}$ & Sesuai \\
\hline $\begin{array}{l}\text { Memilih Menu } \\
\text { Home }\end{array}$ & $\begin{array}{l}\text { Menampilkan Halaman } \\
\text { Home }\end{array}$ & Dapat masuk ke Halaman Home & Sesuai \\
\hline $\begin{array}{l}\text { Memilih Menu } \\
\text { Setting }\end{array}$ & $\begin{array}{lr}\text { Menampilkan } & \text { Halaman } \\
\text { Sub menu } & \text { Manage } \\
\end{array}$ & Dapat daftar dan masuk halaman submenu masing masing & Sesuai \\
\hline
\end{tabular}




\begin{tabular}{|l|l|l|l|}
\hline & $\begin{array}{l}\text { Menu, Manage User, } \\
\text { Informasi }\end{array}$ & & \\
\hline $\begin{array}{l}\text { Memilih Adm } \\
\text { PDB }\end{array}$ & $\begin{array}{l}\text { Menampilkan halaman } \\
\text { sub menu seperti Biodata } \\
\text { peserta }\end{array}$ & Dapat daftar dan masuk halaman submenu masing masing & Sesuai \\
\hline $\begin{array}{l}\text { Memilih Menu } \\
\text { Login }\end{array}$ & $\begin{array}{l}\text { Menampilkan halaman } \\
\text { login }\end{array}$ & Masuk kedalam kelola sistem penerimaan siswa baru & Sesuai \\
\hline $\begin{array}{l}\text { Memilih Menu } \\
\text { Cetak }\end{array}$ & $\begin{array}{l}\text { Menampilkan submenu } \\
\text { cetak data peserta } \\
\text { peserta }\end{array}$ & Dapat daftar dan masuk halaman submenu masing masing & Sesuai \\
\hline $\begin{array}{l}\text { Memilih Menu } \\
\text { Logout }\end{array}$ & $\begin{array}{l}\text { Menampilkan halaman } \\
\text { utama }\end{array}$ & Menuju halaman utama & Sesuai \\
\hline
\end{tabular}

Dari pengujian menggunakan metode black box diatas, seluruh tampilan dan konten telah berfungsi dengan semestinya, dan dapat disimpulkan bahwa perangkat lunak yang dibangun bebas dari kesalahan fungsional.

\section{SIMPULAN}

Berdasarkan hasil penelitian dan pembahasan, maka dapat disimpulkan sebagai berikut: Pengembangan Sistem Penerimaan Siswa Baru yang di bangun dapat digunakan sekolah untuk mempermudah proses penerimaan siswa baru dan dapat di terima dengan baik, fungsi dari aplikasi dapat berjalan dengan baik, hal ini dibuktikan dengan menggunakan blackbox, dapat disimpulkan bahwa aplikasi telah berjalan sesuai dengan yang diharapkan.

\section{UCAPAN TERIMA KASIH}

Puji syukur penulis panjatkan kepada Allah SWT, karena atas berkat dan rahmat-Nya, penulis dapat menyelesaikan penelitian ini. Penulisan Penulis menyadari bahwa, tanpa bantuan dan bimbingan dari berbagai pihak, dari masa perkuliahan sampai pada penyusunan penelitian ini. Oleh karena itu, penulis mengucapkan terima kasih kepada:

1. Bapak Dr.H.M. Nasrullah Yusuf S.E, M.B.A., selaku Rektor Universitas Teknokrat Indonesia;

2. Bapak Dr. H. Mahathir Muhammad, S.E., M.M., selaku Dekan Fakultas Teknik dan Ilmu Komputer, Universitas Teknokrat Indonesia;

3. Ibu Dyah Ayu Megawaty, M. Kom. selaku Ketua Program S1 Informatika, Fakultas Teknik dan Ilmu Komputer, Universitas Teknokrat Indonesia;

\section{REFERENSI/DAFTAR PUSTAKA}

Ahmad, I. et al. (2019) 'Penerapan Algoritma Rekomendasi Pada Aplikasi Rumah Madu Untuk Perhitungan Akuntansi Sederhana Dan Marketing Digital', IIB Darmajaya, pp. 38-45.

Darwis, D. et al. (2020) 'Aplikasi Sistem Informasi Geografis Pencarian Puskesmas Di Kabupaten Lampung Timur', Jurnal Komputer dan Informatika, 15(1), pp. 159-170.

Destiningrum, M. and Adrian, Q. J. (2017) 'Sistem Informasi Penjadwalan Dokter Berbassis Web Dengan Menggunakan Framework Codeigniter (Studi Kasus: Rumah Sakit Yukum Medical Centre)', Jurnal Teknoinfo, 11(2), p. 30. doi: 10.33365/jti.v11i2.24.

Megawaty, D. A. et al. (2020) 'SISTEM MONITORING KEGIATAN AKADEMIK SISWA', 14(2), pp. 98-101.

Mulyadi (2011) 'Sistem informasi akuntansi', Salemba Empat Jakarta.

Mulyanto, A., Nurhuda, Y. A. and Khoirurosid, I. (2017) 'Sistem kendali lampu rumah menggunakan smartphone Android', Jurnal Teknoinfo, 11(2), pp. 48-53.

Rahmanto, Y., Hotijah, S. and Damayanti (2020) 'PERANCANGAN SISTEM INFORMASI GEOGRAFIS KEBUDAYAAN LAMPUNG BERBASIS MOBILE', JDMSI, 1(3), pp. 19-25.

Romney, M. et al. (2012) Accounting Information Systems Australasian Edition. Pearson Higher Education AU.

Setiawansyah, Sulistiani, H. and Darwis, D. (2020) 'Penerapan Metode Agile untuk Pengembangan Online Analytical Processing ( OLAP ) pada Data Penjualan ( Studi Kasus : CV Adilia Lestari )', Jurnal CoreIT, 6(1), pp. 50-56.

Sidik, B. (2018) 'Framework CodeIgniter: Menggunakan Framework CodeIgniter 2. x untuk Memudahkan pengembangan Pemrograman Aplikasi WEB dengan PHP 5'. Informatika. 
Sintaro, S., Surahman, A. and Prastowo, A. T. (2020) 'PENERAPAN WEB WALKERS SEBAGAI MEDIA INFORMASI UNTUK PERBANDINGAN MANUAL BREWING COFFEE DI INDONESIA', JSiI (Jurnal Sistem Informasi), 7(2), pp. 132-137.

Wulandari, Y. and Sulistiani, H. (2020) 'RANCANG BANGUN APLIKASI PRESENSI SMS GATEWAY BERBASIS WEB DENGAN FRAMEWORK CODEIGNITER PADA', 1(1), pp. 43-50. 